\title{
Protein DJ-1
}

National Cancer Institute

\section{Source}

National Cancer Institute. Protein DJ-1. NCI Thesaurus. Code C104716.

Protein DJ-1 (189 aa, $\sim 20 \mathrm{kDa}$ ) is encoded by the human PARK7 gene. This protein plays a role in the downregulation of apoptosis. 